\title{
Phytochemical, Antioxidant, Proximate, and Selected Mineral Status of Egyptian Citrus paradisi Fruit obtained from Wamakko Local Government Area of Sokoto State, North-western Nigeria
}

\author{
Bandilkilima Ibrahim, Ogbiko Cyril*
}

\begin{abstract}
The search for new antioxidant compounds and minerals to combat the nutritional needs of the populace of Nigeria is on the increase. This study investigates the phytochemical composition, antioxidant, proximate, and mineral status of Egyptian Citrus paradise: A popular citrus fruit consumed in Wamakko Local Government Area of Sokoto State using standard procedures. The result revealed that the presence of important phytoconstituents, namely, flavonoids, terpenoids, saponins, phenolics, cardiac glycosides, and reducing sugars with alkaloid was reported to be absent. The juice concentrates exhibit an appreciable but significantly lower $(P<0.05)$ 1, 1-diphenyl-1-picryl-hydrazylradical free screening activity compared to the reference antioxidant. The result of the vitamin, proximate, and mineral analysis confirms the concentrate to be a rich source of Vitamin C, minerals such as sodium, magnesium, potassium, calcium, as well as a moderately to poor source of carbohydrate, lipid, protein, fiber, and potassium. These findings will greatly help nutritionist in properly making nutrition recommendations to meet the nutritional priorities of the populace.
\end{abstract}

Keywords: 1, 1-Diphenyl-1-picryl-hydrazylradical, Concentrate, Mineral, Nutritional, Phytochemical

Asian Pac. J. Health Sci., (2020); DOI: 10.21276/apjhs.2020.7.3.1

\section{INTRODUCTION}

Health and nutritional problems continue to be of increasing concern worldwide. Malnutrition-related disease conditions constitute a serious global health problem in developing countries like Nigeria, especially among its rural populace, even though seasonal fruits are available among all aged peoples. ${ }^{[1]}$ Fruits have been known to form an integral composition of human diet since prehistoric times and have become a culture in developed and developing to incorporate fruits to meals. ${ }^{[2]}$ Fruits are frequently consumed in rural communities where they serve not only as a suitable alternative sources of fresh enzymes, coenzymes, vitamins, and essential nutrients to the body but are also relatively cheap to procure. ${ }^{[3,4]}$ Minerals are inorganic substances required by an organism in small amount required for the maintenance of vital processes essential for life. ${ }^{[5]}$ Fruits have been established to be an excellent source of nutrients like minerals as they play a physiological role, particularly in the body metabolism where they play a key role in the general well-being of the body as well as in the cure of several diseases. ${ }^{[6]}$

Free radicals are often generated in vivo from normal physiological processes where they are implicated in different disease conditions ranging from aging, atherosclerosis, and neurodegenerative diseases. ${ }^{[7,8]}$ Natural antioxidants from plant sources such as food and fruits are potent source of antioxidants and effective in the protection from free radical related oxidative stress. $^{[9,10]}$

An estimated 100 million tons of citrus fruits are produced annually, thereby making the citrus family the largest contributor to the world's fruit production. ${ }^{[1]}$ Citrus is one of the largest plant species known, consisting of 40 species that are distributed around the world. ${ }^{[12]}$ In recent years, scientists and nutritionists
Department of Pure and Applied Chemistry, Faculty of Science, Usmanu Danfodiyo University Sokoto, Sokoto State, Nigeria

Corresponding Author: Ogbiko Cyril, Department of Pure and Applied Chemistry, Faculty of Science, Usmanu Danfodiyo University Sokoto, Sokoto State, Nigeria. Tel.: +234-808-0398-933. Email: cyril.ogbiko@udusok.edu.ng

How to cite this article: Ibrahim B, Cyril O. Phytochemical, Antioxidant, Proximate, and Selected Mineral Status of Egyptian Citrus paradisi fruit obtained from Wamakko Local Government Area of Sokoto State, North-western Nigeria. Asian Pac. J. Health Sci., 2020; 7(3):1-4

Source of support: Nil

Conflicts of interest: None

Received: 18/03/2020 Revised:30/05/2020 Accepted:07/06/2020

have started believing in the therapeutic role of valuable vitamins and essential nutrients. ${ }^{[13,14]}$ Some plants contain significant amount of minerals of which the presence and quantity depend on the plant family, history, and phytoconstituents inherent in the plant. ${ }^{[15]}$

Juices from citrus fruits are consumed majorly because of their nutritional value, bioactive compounds such as phenolics, flavonoids, and vitamins among others as they are required for the maintenance of good health and prevention of diseases. ${ }^{[16,17]}$ They are believed to be responsible for a wide range of protective health benefits including antioxidative, anti-inflammatory, antitumor, and antimicrobial activities. ${ }^{[12,18]}$ This study was, therefore, aimed at evaluating the phytochemical composition, nutritive values by analyzing quantitatively the carbohydrate, Vitamin C, and essential minerals of Egyptian Citrus paradise fruit popularly consumed in Wamakko Local Government Area of Sokoto State. 


\section{Materials and Methods}

\section{Collection and Identification of Fruit}

Fresh fruits were purchased from street vendors in Wamakko Local Government Area of Sokoto State, Nigeria. The fruits were identified by a plant botanist in the Botany unit of the Department of Biological Sciences, Usmanu Danfodiyo University Sokoto, Sokoto State, Nigeria. All the analyses were presented as mean of triplicate analysis was applicable.

\section{Preparation of Fruit Juice Concentrates}

The fruits were rinsed thoroughly with distilled water and were cut into halves. The juice was extracted from the fruits using a juice extractor. The fruit juices were then lyophilized and the concentrates obtained were preserved at $4^{\circ} \mathrm{C}$ in airtight containers until subsequent use.

\section{Phytochemical Screening}

Simple chemical tests to detect the presence of secondary metabolites were performed using standard procedures. ${ }^{[19-21]}$

\section{Determination of 1, 1-Diphenyl-1-picryl- hydrazylradical (DPPH) Radical Scavenging Activity}

Radical scavenging activity of the fruit juice concentrate against the DPPH was performed in accordance with the procedures outlined by Jain et al. ${ }^{[22]} \mathrm{A} 0.01-0.2 \mu \mathrm{g} / \mathrm{mL}$ of the concentrate was prepared in methanol and used for the assay. A $0.1 \mathrm{mM} \mathrm{DPPH}$ in methanol was prepared, and $1.0 \mathrm{~mL}$ of this solution was mixed with $3.0 \mathrm{~mL}$ of different concentrations ranging from 0.01 to $0.2 \mathrm{mg} / \mathrm{mL}$ of the concentrate. The reaction mixture was vortexed thoroughly and left in the dark at room temperature for $30 \mathrm{~min}$. The absorbance of the mixture was measured spectrophotometrically at $517 \mathrm{~nm}$. Ascorbic acid was used as standard with the same concentrations as the test solution. The ability to scavenge DPPH radical was determined using the expression:

$$
\operatorname{DPPH} \operatorname{RSA}(\%)=\frac{\mathrm{A}_{0}-\mathrm{A}_{1}}{\mathrm{~A}_{0}} \times 100
$$

Where, $\mathrm{RSA}=$ radical scavenging activity; $\mathrm{A}_{0}=$ absorbance of DPPH radical + methanol, $A_{1}=$ absorbance of $D P P H$ radical + fruit concentrate/standard. Concentrations of 10, 25, 50, 100, and 200 $\mu \mathrm{g} / \mathrm{mL}$ were used for the study.

\section{Vitamin C, Proximate, and Mineral Analyses}

Ascorbic acid (Vitamin C) content was estimated by the 2,4-dinitrophenylhydrazine method. ${ }^{[23]} \mathrm{A} 5.0 \mathrm{~g}$ of the edible portion of the fruit was weighed into a crucible and the moisture content was determined by weight loss on drying at $105^{\circ} \mathrm{C}$ for $6 \mathrm{~h}$. The nitrogen content $(\mathrm{N})$ was determined by the Kjeldahl procedure. ${ }^{[24]}$ Using $\mathrm{N} \times 6.25$, the total protein content was determined. Lipid, ash, and fiber contents were determined according to the procedures outlined by AOAC. ${ }^{[24]}$ The total carbohydrate was determined by simple difference as follows: Carbohydrate $=100-(\%$ Ash + $\%$ Crude protein $+\%$ Crude lipid + \%Crude fiber) g/100 g. ${ }^{[25]}$ For the mineral analyses, $5.0 \mathrm{~g}$ of the edible portion was wet-ashed using a mixture of $18 \mathrm{M}$ sulfuric acid, $12 \mathrm{M}$ perchloric acid, and $16 \mathrm{M}$ nitric acid [0.5:1.0:0.5 v/v/v]. ${ }^{[26]} \mathrm{Na}, \mathrm{K}, \mathrm{Ca}, \mathrm{Mg}$, and $\mathrm{P}$ were analyzed using the procedures outlined by Walinga et al. ${ }^{[27]}$

\section{Statistical Analysis}

The data were applicable which were expressed as mean \pm standard deviation of three replicates. The data from the antioxidative assay were subjected to one-way analysis of variance.

\section{Results}

The phytochemical screening of the fruit juice concentrates showed the presence of important secondary metabolites which is presented in Table 1.

The DPPH radical scavenging assay is a commonly used tool for accessing the antioxidant capacity of natural products because it is relatively cheap to perform and possesses a high speed of completion. The results of the antioxidative screening are presented in Figure 1 with the $50 \%$ inhibitory concentration of the fruit juice concentrates in comparison to ascorbic acid standard which is presented in Table 2.

The Vitamin C, proximate, and selected mineral compositions of the Egyptian citrus fruit are presented in Tables 3 and 4, respectively.

\section{Discussion}

Phytochemicals are the invaluable chemicals present in plant from which they possess varying degrees of pharmacological activities. They serve as a major source of raw materials as well as aid in the biological actions for which they are identified in folklore medicine. ${ }^{[28]}$ The phytochemical composition of the fruit juice concentrates revealed that the presence of important phytoconstituents, namely, flavonoids, terpenoids, saponins, phenolics, cardiac glycosides, and reducing sugars with alkaloid was reported to be absent [Table 1]. These results agree partly with the findings of Ehigbai et al., ${ }^{[29]}$ Rauf et al., ${ }^{[30]}$ and Mathew et al. $^{[31]}$ who also reported the presence flavonoids, terpenoids, phenolics, and reducing sugars as well as the absence of alkaloids. The findings from this study differ in the reported presence of saponins and glycosides. These differences may be attributed to differences in species as well as the geographical location which is known to affect both the morphology and expression of phytochemicals. ${ }^{[32,33]}$

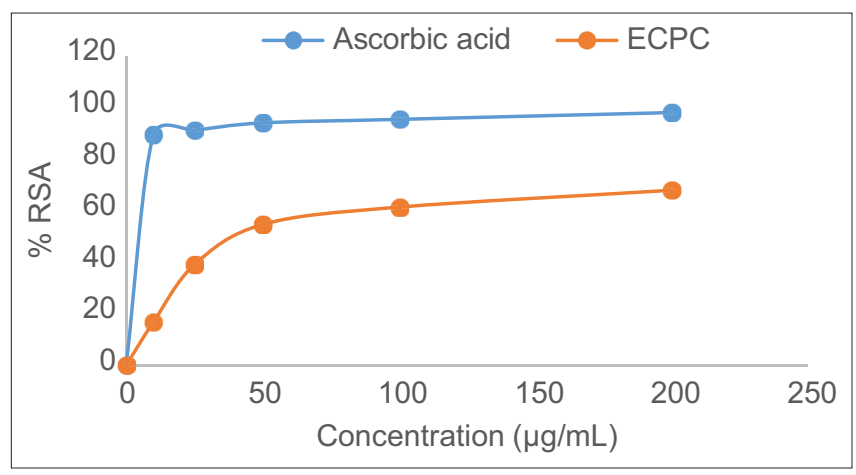

Figure 1: 1, 1-Diphenyl-1-picryl-hydrazylradical radical scavenging activity of the citric fruit concentrate and the synthetic antioxidant (ascorbic acid) at different concentrations. Each point is a mean from triplicate measurement. ECPC: Egyptian Citrus paradisi concentrate 
Table 1: Phytochemical composition of the Egyptian Citrus paradisi fruit juice concentrates

\begin{tabular}{lll}
\hline Phytochemicals & Test(s) conducted & Observation \\
\hline Flavonoid & Shinoda & Reddish color was observed \\
& Alkaline reagents & Intense yellow color was formed \\
Terpenoid & Salkowski's & Appearance of golden yellow ring at the interface \\
Saponin & Frothing & Foam was formed \\
Alkaloid & Mayer's & No precipitate formed \\
& Wagner's & No precipitate formed \\
& Dragendorff's & No precipitate formed \\
Phenolics & Ferric chloride & Bluish-black color appeared \\
Reducing sugars & Molisch's & Violet ring was formed at the junction \\
& Fehling's & Red precipitate was formed \\
Cardiac glycoside & Keller-Killiani's & Violet ring at the interface of two liquid layers \\
\hline
\end{tabular}

+ : Presence of phytochemical, -: Absence of phytochemical

Table 2: $50 \%$ inhibitory concentration of the citrus fruit concentrate and the ascorbic acid standard

\begin{tabular}{lc}
\hline Parameter & $I C_{50}$ \\
\hline Egyptian Citrus paradisi concentrate & 13.42 \\
Ascorbic acid standard & 3.89 \\
\hline
\end{tabular}

$\mathrm{IC}_{50}: 50 \%$ inhibitory concentration

Table 3: The Vitamin C and proximate composition of Egyptian Citrus paradisi fruit juice

\begin{tabular}{lc}
\hline Parameters & $\% \pm S D$ \\
\hline Vitamin C $(\mathrm{mg} / 100 \mathrm{~g})$ & $72.23 \pm 2.32$ \\
Moisture & $87.09 \pm 0.71$ \\
Crude ash & $4.54 \pm 0.11$ \\
Crude lipid & $0.17 \pm 0.02$ \\
Crude fiber & $0.23 \pm 0.01$ \\
Crude protein & $0.67 \pm 0.01$ \\
Carbohydrate $(\mathrm{g} / 100 \mathrm{~g})$ & $7.30 \pm 0.21$ \\
\hline
\end{tabular}

Mg: Milligram, g: Gram, KJ: Kilojoules, \%: Percentage, SD: Standard deviation

Table 4: Selected mineral analyses of Egyptian Citrus paradisi fruit juice

\begin{tabular}{lc}
\hline Parameters & Content $(\mathrm{mg} / 100 \mathrm{~g})$ \\
\hline $\mathrm{Na}$ & $27.03 \pm 0.09$ \\
$\mathrm{~K}$ & $100.73 \pm 1.02$ \\
$\mathrm{Ca}$ & $27.42 \pm 1.11$ \\
$\mathrm{Mg}$ & $17.17 \pm 1.42$ \\
$\mathrm{P}$ & $24.92 \pm 1.73$ \\
\hline
\end{tabular}

DPPH is usually used as a reagent to evaluate free radical scavenging activity of antioxidants because it is as table free radical which accepts an electron or hydrogen radical to become a stable diamagnetic molecule. ${ }^{[8]}$ The fruit concentrates exhibit a reasonable antioxidant potential but not statistically significant $(P<0.05)$ to that of the ascorbic acid standard [Table 2]. This observed activity could be related to the presence of phenolic compounds such as flavonoids which is known to play a notable pharmacological and biochemical roles including radical scavenging properties ${ }^{[34]}$ as well as in the stabilization of lipid oxidation and may contribute directly to antioxidative action. ${ }^{[35]}$ The results showed that the juice concentrates are not as effective as ascorbic acid in scavenging free radicals probably because the latter contain more purified compounds than the former.

Vitamins are accessory factors which are required in diet to maintain good health and well-being of an individual of which fresh fruits are a veritable source. The fruit juice showed a rich source of Vitamin C [Table 3], moisture which could serve to partly quench thirst in dehydrating conditions, an appreciable source of minerals as revealed by its ash value and a poor source of carbohydrate, lipid, fiber, and protein. The composition of fruits nutrients and vitamins may vary due to climatic factors, nature of the cultivating soil, as well as the maturity of the fruit itself. ${ }^{[1]}$

The studied minerals are the five $(\mathrm{Na}, \mathrm{K}, \mathrm{Ca}, \mathrm{Mg}$, and $\mathrm{P})$ major macronutrients. These minerals are known to play significant functions like while sodium, phosphorus, and potassium play a key role in active transport across the cell membrane as well as in the maintenance of osmotic balance. Magnesium activates enzymatic systems while calcium is responsible for metabolisms in the bone and in the nerves. ${ }^{[3,36]}$ Fruits notably citrus fruits are known to be a rich source of the investigated minerals except phosphorus. The findings from the study revealed the concentration of 27.03 $\mathrm{mg} / 100 \mathrm{~g}$ for sodium, $100.73 \mathrm{mg} / 100 \mathrm{~g}$ potassium, $72.42 \mathrm{mg} / 100$ $\mathrm{g}$ calcium, and $24.92 \mathrm{mg} / 100 \mathrm{~g}$ magnesium. The concentration of $11.17 \mathrm{mg} / 100 \mathrm{~g}$ was reported for phosphorus. These findings compare favorably with findings of other researchers. ${ }^{[1,37-39]}$ Fruits mineral composition varies greatly with topographical factors as well the nature of cultivating soil, climatic factors such as the amount of rainfall as well as the maturity of fruits before harvest. ${ }^{[1]}$

\section{Conclusion}

The information provided from this research shows that the Egyptian Citrus paradise popularly consumed in Sokoto metropolis is a rich source of Vitamin C as well as important phytochemicals which have been established to play pivotal role in scavenging damaging free radicals. It is also an important source of minerals to human through dieting, especially $\mathrm{Na}, \mathrm{K}, \mathrm{Ca}$, and $\mathrm{Mg}$, as well as aid nutritionists to effectively make nutritional recommendation which will help greatly in the diet health assessment in Nigeria.

\section{References}

1. Dipak KP, Ranajit KS. Nutrients, vitamins and mineral contents in common citrus fruits in the Northern region of Bangladash. Pak J Biol Sci 2004;7:238-42.

2. Reis $\mathrm{CP}$, Kline $\mathrm{S}$, Weaver SO. Impact of commercial eating on nutrients adequacy. J Am Diet Assoc 1987;87:463-8.

3. Muhammad S, Umar KJ, Sani NA, Muhammad S. Evaluation of nutritional and anti-nutritional profile of ginger bread plum (Neocarya macrophtlla) seed kernel. Int J Sci Technol 2015;4:361-7.

4. Hassan LG, Bagudo BU, Aliero AA, Umar KJ, Abubakar L, Sani NA. Evaluation of nutrient and anti-nutrient content of Parkia biglobosa L. flower. Niger J Basic Appl Sci 2011;19:76-80.

5. Doris MC. Minerals. In: Kraus MV, editor. Food Nutrition and Diet Therapy. $7^{\text {th }}$ ed. Philadelphia, PA: W.B. Saunders Company; 1984. p. $144-80$. 
6. Prasad AS. Essential and Toxic Elements in Human Health and Disease: An Update. New York: Wiley-Liss; 1993.

7. Sahreen S, Khan MR, Khan RA. Comprehensive assessment of phenolics and antiradical potential of Rumex hastatus D. Don. Roots. BMC Complement Altern Med 2004;14:47-53.

8. Ogbiko C, Eboka CJ, Tambuwal AD. Extraction and fractionation of whole seed black plantain (Plantago rugelii Decne) for in vitro antioxidant, antibacterial and phytochemical screening. J Appl Sci Environ Manage 2018;22:613-8.

9. Auudy B, Ferreira M, Blasina F, Lafon L, Arredondo F, Dajas F, et al. Screening of antioxidant activity of three Indian medicinal plants traditionally used for the management of neurodegenerative diseases. J Ethnopharmacol 2003;84:131-8.

10. Jensen GS, Wu X, Patterson KM, Barnes J, Carter SG, Scherwitz L, et al. In vitro and in vivo antioxidant and anti-inflammatory capacities of an antioxidant-rich fruit and berry juice blend. Results of a pilot and randomized, double-blinded, placebo-controlled, crossover study. J Agric Food Chem 2008;56:8326-33.

11. Jwanny EW, El-Sayed ST, Salem AM, Mabrouk NA, Shehata AN. Fractionation, identification and biological activities of Egyptian citrus peel extracts. Aust J Basic Appl Sci 2012;6:34-40.

12. Karimi E, Oskoueian E, Hendra R, Oskoueian A, Jaafar HZ. Phenolic compounds characterization and biological activities of Citrus aurantium bloom. Molecules 2012;17:1203-18.

13. Udayakumar R, Begum VH. Elemental analysis of medicinal plants used in controlling infectious diseases. Hamdard Med 2004;67:35-6.

14. Vassen HA. Some elements in domestic and imported fresh foods marketed in the Netherlands. Z Lebensen Unters Forsh 1991;193:351.

15. Houghton P. Use of medicinal plants in CNS disorders. In: Yanniv Z, Bachrach U, editors. Handbook of Medicinal Plants. India: Harworth Press; 2007. p. 234.

16. Boudries H, Madani K, Touati N, Souagui S, Medouni S, Chibane M. Pulp antioxidant activities, mineral contents and juice nutritional properties of Algerian clementine cultivars and mandarin. Afr J Biotechnol 2012;11:4258-67.

17. Rekha C, Poornima G, Manasa M, Abhipsa V, Pavithra DJ, Kumar HT, et al. Ascorbic acid, total phenol content and antioxidant activity of fresh juices of four ripe and unripe citrus fruits. Chem Sci Trans 2012;1:303-10.

18. Aruoma OI, Landes B, Ramful-Baboolall D, Bourdond E, NeergheenBhujune V, Wagnerf $K$, et al. Functional benefits of citrus fruits in the management of diabetes. Prev Med 2012;54:S12-6.

19. Sofowora A. Screening plants for bioactive agents. In: Medicinal Plants and Traditional Medicine in Africa. Ibadan: Spectrum Books Ltd.; 1982.

20. Stalh E. Drug Analysisby Chromatography and Microscopy: A Practical Supplement to Pharmacopoeias. $1^{\text {st }}$ ed. Ann Arbor, Michigan: Ann Arbor Science Publishers; 1973. p. 219-24.

21. Trease GE, Evans WC. Pharmacognosy. $11^{\text {th }}$ ed. London: Churchill Livingstone Harcourt Health Service; 1978. p. 60-75.

22. Jain A, Soni M, Deb L, Jain A, Rout S, Gupta V, et al. Antioxidant and hepatoprotective activity of ethanolic and aqueous extracts of
Momordica dioica Roxb. Leaves. J Ethnopharmacol 2008;115:61-6.

23. Roe $\mathrm{JH}$, Asterlin MJ. The determination of dehydro ascorbic acid and ascorbic acid in plant tissue by the 2,4-dinitro-phenylhydrazine method. J Biol Chem 1969;152:511-3.

24. Association of Official Analytical Chemist. In:Williams S, editor. Official Methods of Analysis. 16 th ed. United States: Association of Official Analytical Chemist; 1995.

25. Hassan LG, Dangoggo SM, Umar KJ, Saidu I, Folorunsho FA. Proximate, minerals and anti-nutritional factors of Daniellia oliveri seed kernel. Chemclass J 2008;5:31-6.

26. Davis NT, Hillary R. An evaluation of phytate, zinc, copper, iron and manganese contents and zinc bioavailability from soya-based textured vegetables, proteins and meat substitutes or meat extender. Br J Nutr 1978;41:579-91.

27. Walinga I, Van-Veak VW, Houba VI, Van-der lee JJ. Plant Analysis, Procedures Soil and Plant Analysis. Wageningen Nertherland: Springer; 1989. p. 18-27.

28. Oikeh El, Oriakhi K, Omoregie ES. Proximate analysis and phytochemical screening of Citrus sinensis fruit wastes. Bioscientist 2013;1:164-70.

29. Ehigbai IO, Ehimwenma SO, Faith EO, Kelly O. Phytochemical, antimicrobial, and antioxidant activities of different citrus juice concentrates. Food Sci Nutr 2016;4:103-9.

30. Rauf A, Uddin G, Ali J. Phytochemical analysis and radical scavenging profile of juices of Citrus sinensis, Citrus anrantifolia, and Citrus limonum. Org Med Chem Lett 2014;4:5-11.

31. Mathew BB, Jatawa SK, Tiwaari A. Phytochemical analysis of Citrus limonum pulp and peel. Int J Pharm Pharm Sci 2012;4:269-371.

32. Folkers A, Huve K, Ammann C, Dindorf T, Kesselmeier J, Kleist E, et al. Methanol emissions from deciduous tree species: Dependence on temperature and light intensity. Plant Biol 2008;10:65-75.

33. Shen $\mathrm{H}$, Tang $\mathrm{Y}$, Muraoka $\mathrm{H}$, Washitani I. Characteristics of leaf photosynthesis and simulated individual carbon budget in Primula mutans under contrasting light and temperature conditions. J Plant Res 2008;121:191-200.

34. Prasad KN, Yang B, Dong X, Jiang G, Zhang H, Xie H. Flavonoid contents and antioxidant activities from Cinnamomum species. Innov Food Sci Emerg Technol 2009;10:627-32.

35. Gursoy N, Sarikurkcu C, Cengiz M, Solak MH. Antioxidant activities, metal contents, total phenolics and flavonoids of seven Morchella species. Food Chem Toxicol 2009;47:2381-8.

36. Hassan LG, Sokoto AM, Ngaski MA, Anka SA, Chanchangi BM, Umar KJ, et al. Nutritional and anti-nutritional analyses of Hura crepitans seeds cultivated in Sokoto North L.G.A, North-Western Nigeria. Bayero J Pure Appl Sci 2018;11:126-30.

37. Gopalan C, Rama BV, Rama S, Balasubramanian SC. Nutritive Value of Indian foods. Hyderabad, India: National Institute of Nutrition, Indian Council of Medical Research; 1993.

38. Kamaluddin A. Symposium on local food and nutrition. $3^{\text {rd }}$ ed. Dhaka, Bangladesh: INFS, University of Dhaka; 1983.

39. Begum H, Rahaman M, Sayeed, S. Mineral content in common fruits of Bangladesh. Bangladesh J Nutr 2002;15:57-62. 